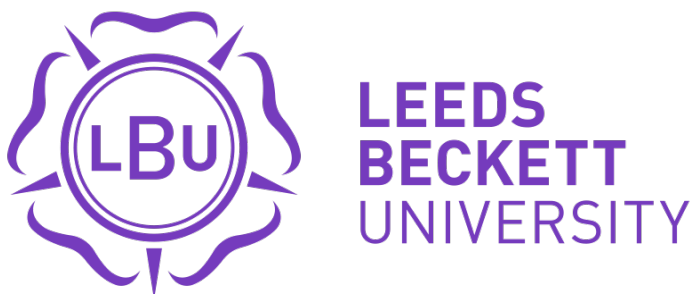

\section{Citation:}

Fletcher, $T$ (2011) The making of English cricket cultures: Empire, globalization and (post) colonialism. Sport in Society, 14 (1). 17 - $36 . \quad$ ISSN 1743-0437 DOI: https://doi.org/10.1080/17430437.2011.530006

Link to Leeds Beckett Repository record:

https://eprints.leedsbeckett.ac.uk/id/eprint/2313/

Document Version:

Article (Updated Version)

The aim of the Leeds Beckett Repository is to provide open access to our research, as required by funder policies and permitted by publishers and copyright law.

The Leeds Beckett repository holds a wide range of publications, each of which has been checked for copyright and the relevant embargo period has been applied by the Research Services team.

We operate on a standard take-down policy. If you are the author or publisher of an output and you would like it removed from the repository, please contact us and we will investigate on a case-by-case basis.

Each thesis in the repository has been cleared where necessary by the author for third party copyright. If you would like a thesis to be removed from the repository or believe there is an issue with copyright, please contact us on openaccess@leedsbeckett.ac.uk and we will investigate on a case-by-case basis. 


\title{
The making of English cricket cultures: Empire, globalisation and (post) colonialism
}

\author{
Paper accepted by Sport in Society. \\ Dr. Thomas Fletcher \\ Carnegie Faculty for Sport and Education, Leeds Metropolitan University, UK.
}

\begin{abstract}
The aim of this article is to understand how English cricket cultures have been made, negotiated and, ultimately resisted, in the context of (post) colonialism. I draw upon research undertaken with white and British Asian cricketers in Yorkshire to identify the place and significance of cricket within the everyday lives of British Asian communities. Over the last decade the number of British Asian cricketers progressing into the upper echelons of the game (mainly the English County Championship) has increased. Many within the game (mainly white people) have used these figures to argue that English cricket is now 'colourblind'. However, I argue that representation is not the equivalent to acceptance and integration and present evidence to suggest that racial prejudice and discrimination, not to mention, inaccurate and essentialised cultural stereotypes of British Asian cricketers remain firmly and routinely embedded in aspects of the sport at all levels. I argue that the ability of British Asians to resist the hegemonic structures of white 'Englishness', by asserting their own distinctive post-colonial identities in cricket, is paramount to their everyday negotiations of power and racism.
\end{abstract}

Keywords: British Asians, British Empire, Cricket, Post-colonial identities, Racism, Resistance.

\section{English cricket: A timely examination of British Asian communities}

The aim of this article is to understand how English cricket cultures have been made in colonial contexts. This necessitates an examination of, not only how these cultures were made and transferred by the agents of imperialism, but how attitudes, values and playing styles associated with cricket in the British Empire have been (and continue to be) received, re-made and often resisted by different ethnic groups. For the purposes of this article, I am particularly interested in how British Asian communities utilise cricket (and specifically how they invest cricket with particularly 'Asian' cultural practices) in order to resist those cultural practices commonly associated with white 'Britishness' that emerged from the British Empire. ${ }^{1}$ Indeed, in the case of cricket, and for British Asians, their ability to resist the hegemonic structures of white 'Englishness', by asserting their own distinctive post-colonial identities, is paramount to their everyday negotiations of power and racism.

Whilst the number of Black British cricketers (both amateur and professional) has declined over the last decade, there has been a marked increase in the number of players from British Asian backgrounds. ${ }^{1}$ In fact, Burdsey argues that, at the professional level at least, British Asian players are now over-represented compared to their numbers in the overall population. ${ }^{2}$ Due to dominant claims that British sport is meritocratic and that recruitment and selection procedures are 'colour-blind', an increasingly widespread perception has emerged - within the sport itself,

1 The term Black British is used to delineate individuals of African and/or Caribbean (AfroCaribbean) descent who were either born in Britain, or whom have migrated to Britain and claimed British citizenship. The term British Asian is similarly used in this article to delineate individuals of South Asian descent who were either born in Britain, or whom have migrated to Britain and claimed British citizenship. The term South Asian is also used to broadly delineate people from the Indian subcontinent. None of these categorisations are wholly accurate, but they are known and understood. 
among politicians and in sections of the media - that this numerical representation signifies the eradication of racism from English cricket. ${ }^{3}$ Indeed, historically, representatives of English cricket have been reluctant to acknowledge that racism exists in the game. Former President of the Marylebone Cricket Club (MCC) ${ }^{4}$, Tim Rice, for instance, once accused members of the Hit Racism for Six campaign of manufacturing a problem of racism in cricket where none existed. He claimed that cricket was 'one of the least racist features of British Society'. ${ }^{5}$ It would be easy to accept the figures of British Asian participation as a sign of cricket's inclusivity. However, representation is not the equivalent to acceptance and integration. On the contrary, a great deal of evidence exists to suggest that racial prejudice and discrimination are still routinely embedded in aspects of the sport. ${ }^{6}$ Crucially, as a white cricketer myself, I would argue that most people associated with the sport would acknowledge that racism exists. However, it is only within the last two decades that researchers (cricketers and non-cricketers alike) have begun to interact first hand with players and officials involved at the various levels of the game, with the aim of exploring how power and racism are both manifest and challenged.

Existing sociological research into 'race' and cricket has focused predominantly on the excluding and alienating effects of 'Englishness' in international cricket, issues of identity and problems of racism in amateur cricket, or articulations of fandom within diasporic communities. ${ }^{7}$ At the current time, very little research exists that directly focuses on the experiences of British Asians in cricket. This article goes some way to address this. The data used in this article were collected during my doctoral fieldwork which explored the construction, maintenance and contestation of racialised identities in Yorkshire cricket. The fieldwork was undertaken with two culturally contrasting, high level amateur cricket clubs in Sheffield, South Yorkshire - one predominantly white and the other predominantly Asian in membership. ${ }^{8}$ The research, which took place between June 2007 and January 2010, involved a process of in-depth ethnographic fieldwork based on 21 semi-structured interviews, two focus group interviews and participant observation. Both clubs and all respondents have been given pseudonyms. The predominantly white club will hereafter be referred to as 'Sutherland' and the predominantly Asian club referred to as 'Aylesworth'.

English cricket has a long history of inequality and continues to be a bastion for a certain type of hegemonic white masculinity, which excludes many people from minority ethnic communities from being recognised as insiders. This point is particularly relevant given that this research has been conducted in Yorkshire. Cricket has traditionally been a fundamental aspect of Yorkshire's identity. In fact, many have argued that cricket has acted as the single-most important mechanism for exporting Yorkshire identity outside its boundaries. Rob Light (2009) in particular, argues that Yorkshire County Cricket Club (YCCC) served as a crucial mechanism through which metaphors and symbols of Yorkshire cricket and Yorkshire culture became known within and beyond Yorkshire's boundaries. ${ }^{9}$ Naturally, these metaphors and symbols are not always interpreted positively. For many people from minority ethnic backgrounds, Yorkshire cricket is epitomised by the county club (and everything it has stood for), which has historically had a poor relationship with the region's minority ethnic communities. This is best illustrated in reference to YCCC's infamous birthright policy, which restricted participation for the county team to those people born within the county's boundaries. Although all English counties have operated their own birthright policies, Yorkshire's territorial defensiveness was exemplified when it persisted with its policy after other counties had abandoned theirs. In fact, YCCC only abandoned its birthright policy at the end of 1991. For many, the 'birthright' policy was thought to be at the heart of the club's racist and exclusive reputation. ${ }^{10}$ Many people (not just Asian) inside and outside Yorkshire have seen Yorkshire's birthright policy and subsequent long-standing failure to field Asian and Black players in the county first team with any real consistency, as the result of ingrained racism within the club. ${ }^{11}$ Although the policy's strictness was never sacrosanct, it did add to the perception that the club did not welcome 'outsiders' of any description. The heritage of Yorkshire cricket has been constructed around northern, white masculinity and it is well noted that those who embody these identities are keen to protect that heritage from those who do not. During the policy's implementation, for many people in Yorkshire, minority ethnic communities (Asians included) were just not 'Yorkshire' enough; in that, they did not imbue the famous sense of Yorkshire masculinity or possess the famous Yorkshire mentality. Historically, Yorkshire cricketers are 
renowned for playing the game in a particular manner: in a Yorkshire-like way. Batsmen and bowlers alike should be hard, uncompromising and disciplined. Asian cricket has evolved with its own stereotypes attached to it (in Yorkshire at least), which constructed the way Asian people played the game as being incompatible with the Yorkshire way. Indeed, even in the present day, a number of insidious cultural racisms pertaining to Asian cricketers being irrational and unintelligent continue to exist at various levels of Yorkshire cricket. Thus, Yorkshire's historical symbiosis with cricket and (alleged) discriminatory practices makes this research particularly timely. Not only does the research examine the construction and maintenance of these stereotypes over time, it also provides a platform for everyday people (namely British Asians) to respond to them, while also demonstrating how cricket (and sport generally) can provide an important arena for forms of cultural resistance against white racism and concomitant conceptualisations of homogenous Britain.

\section{Homogenous Britain?}

South Asians only began to settle in Britain in significant numbers as a result of British colonial rule in India. ${ }^{12}$ By the late eighteenth and early nineteenth centuries 'adventurers' and small communities of seamen had also begun to settle. ${ }^{13}$ Mass migration from South Asia to Britain did not start until after the Second World War. Given the time of their migration, and the instabilities emerging in the wake of the war (such as poverty and declining industries) surrounding British culture, life was challenging for minority ethnic communities trying to make a new life for themselves. The first generation of settlers undoubtedly experienced a 'sense of loss ... [of] the familiar sights, sounds and smells of their birthplace'. ${ }^{14}$ In addition, many were subject to hostility and racism from indigenous British people because one of the consequences of mass migration was that old certainties regarding (white) British identities and 'Britishness' were questioned. Gilroy argues that dominant responses to such processes promoted, or at least contributed to, a re-homogenisation of the nation's demographic composition, which continued to exclude minority ethnic groups. ${ }^{15}$

National borders are imagined to enclose a particular and separate culture. ${ }^{16}$ Globalisation is one of the main threats to a nation's indigenous culture because global processes (developments in the means of travel in particular) have increased the permeability of national borders to 'alien' people. ${ }^{17}$ Similarly, multiculturalism (a direct result of globalisation) is often perceived as threatening the authenticity of national cultures because it introduces different people, who bring with them different cultures which do not automatically seem compatible with the indigenous culture. During the early phases of migration, South Asians were seen to be introducing irreversible changes to the social composition of Britain. In particular, the main threats were believed to be that they provided competition for jobs and housing, that they had excessively large families, and that they were reluctant to integrate. It is widely assumed that, as national borders become increasingly permeable to 'alien' people, that the ethnic core of the nation becomes defensive..$^{18}$ Indeed, normative codes of 'Englishness' not only maintain the hegemony of, and promote an indigenous ethnic core, they also presume the existence of that core.

Today, even as there are second and third generations of Asian and Black people living in Britain, normative codes of 'Englishness' continue to reproduce them as something which pollutes the purity of 'Englishness'. The reasoning behind this is twofold: firstly, to protect the national culture from infiltration from foreign cultures by maintaining the hegemonic position of the indigenous ethnic core; and secondly, to promote cultural homogeneity. According to Sutherland's Tony, the natural reaction to migration and globalisation is for local, regional and national communities to hold on tight to those symbols, myths, memories, traditions and nostalgia which have helped define their cultural identities: cricket amongst them. ${ }^{19}$ While these sentiments are indicative of a backward looking 'Little Englander' mentality that is racist and narrow-minded, they were shared by a number of the white respondents in this research.

Although there is evidence of insecurities surrounding English and British identities dating back much further than the post Second World War period, it is since this time that everyday people's 
insecurities have been closely scrutinised alongside cricket. Norman Tebbit's 'cricket test' is perhaps the most well cited example. In 1990, in an interview with the Los Angeles Times, British Conservative politician Norman Tebbit accused Britain's migrant communities of failing to sufficiently integrate in British society. Tebbit controversially argued that to live in Britain, migrant communities had to unequivocally assimilate into the British 'way of life'. Central to this was that migrant communities should demonstrate an allegiance to the England cricket team. For Tebbit, a fundamental aspect of assimilation was for any imaginary attachment to one's nation(s) of ancestry (including supporting their national cricket side) to be severed. Tebbit was canny in his decision to choose cricket as his marker of assimilation because for centuries, the ubiquity of cricket in English popular culture has made it synonymous with expressions of 'Englishness', Empire, bourgeois English nationalism and British elitism. ${ }^{20}$ When he made his comments, Tebbit assumed that mass immigration threatened Britain's hegemonic national culture and longterm cohesion. Many people have interpreted the rhetoric of 'cohesion' to represent homogeneity rather than inclusive multiculturalism. ${ }^{21}$ Similar views are currently epitomised by the far Right: the British National Party (BNP) leader Nick Griffin amongst them. ${ }^{22}$ This hankering after homogeneity is, however, becoming increasingly obsolete as even the most stubborn traditionalists (excluding the far Right and I dare say Tebbit) have begun to accept that, in the current era, cultural diversity is inevitable. ${ }^{23}$ Indeed, in the current era of cut-and-mix possibilities, our everyday perceptions of 'Englishness'/'Britishness' have had to change to accommodate diversity. In a society so culturally diverse it is difficult to even assume what English identity is, or means, anymore; if indeed, we ever could have done previously. ${ }^{24}$ In spite of this, English cricket continues to be closely associated with a largely unchanging sense of white 'Englishness'. Indeed, I argue that 'Englishness' is now a greater myth and is more insecure than it has ever been. However, the same insecurities cannot be seen in English cricket.

\section{Common cricket culture: defined by imaginings of Empire?}

Is there something English about cricket? Or is that just the old imperial propaganda? ... Is there something in cricket that links it to the destinies of English people? And which English people? Which England? Or rather, whose?25

Cricket is integral to our understanding of the relationship between colonialism and the British Empire. The story of imperial cricket is really about the colonial quest for identity in the face of the colonisers' search for authority. ${ }^{26}$ Within the British Empire, cricket was an important national symbol of 'Englishness' and, it was widely believed, cricket helped inculcate many of the qualities fundamental to Victorian gentility which the English perceived as being essential to building strong English character. According to J.A. Mangan, it was cricket that emerged, not only as the most prominent sport within the British Empire, but also, as 'the symbol par excellence of imperial solidarity and superiority epitomising a set of consolidatory moral imperatives that both exemplified and explained imperial ambition and achievement'. ${ }^{27}$ Cricket had a responsibility for communicating English moral worth with 'races' less civilised than our own. ${ }^{28}$ It offered an instrumental form of socialisation: presented as a means to a civilised world, promoting team work, obedience to the rules, and respect for 'fair play'. ${ }^{29}$ Within the colonies cricket's elites quite consciously sought to maintain and promote a specific moral code, which revolved around white hegemonic masculinity. According to C.L.R. James phrases such as 'playing with a straight bat', and 'it isn't cricket' became the 'watchwords of manners and virtue and the guardians of freedom and power'. ${ }^{30}$ A good cricketer was also thought to be a good all-round Englishman; 'with positive virtues, loyalty and self-sacrifice, unselfishness, co-operation and esprit de corps and a sense of honour'. ${ }^{31}$ It is this character which the English have tried so fervently to globalise. With this in mind, touring teams from England were responsible for exporting the laws of the game; first to the colonies and the rest of the world thereafter. ${ }^{32}$ It was long believed (within the colonies and dominions) that cricket could strengthen imperial ties. ${ }^{33}$ Indeed, towards the end of the Victorian period, sport had come to play an important role in binding the Empire together. ${ }^{34}$ However, while there are, as Hughson argues, 'points of commonality' to be considered, the cultural experience of cricket differed from one national context within the Empire to another. ${ }^{35}$ Disguised by utterances of meritocracy and social inclusion, however, a very specific agenda of cultural 
homogenisation existed. Rather than binding the Empire via mutual respect, the British tried to bind it around visions of sameness. Ramachandra Guha reflects on this sense of British domination:

In time he [the Indian native] asked to play matches against the rulers. It made sense now to see his eagerness as confirmation of the imperial mission, a pleasing sign of the brown man's readiness to absorb British values ... The rulers convinced themselves that they had actively preached the gospel; that they had taught Indians to play cricket. The British ... converted the Indian to cricket, to thus bind him more firmly; and more happily, to their rule. ${ }^{36}$

However, 'fashions and models are seldom replicated exactly as intended'. ${ }^{37}$ Instead, they are invariably adapted to suit parochial needs and traditions (often delineated in defiance to the hegemonic structures of white 'Englishness').

No doubt cricket played an important role in facilitating British colonialism. However, others have warned that the spread of cricket may have been more accidental, or certainly less ideological. Guha for instance, suggests that, in the early years of colonial expansion, cricket was utilised by homesick expatriate British people as a form of respite; as a means to 're-create memories of life in England'. ${ }^{38}$ Similarly, many of the Asian respondents in this research identified how cricket was currently performing a comparable role for binding the Asian diaspora together. Cricket continues to be a vital exponent of ethnic identities and, during times of migration, was important for fostering some symbolic sense of cultural stability amongst diasporic communities. As migrant families arrived in Britain throughout the 1960s onwards, cricket acted as a vehicle to encourage different ethnic groups to socialise with white people and integrate into existing British culture. Cricket also alleviated feelings of isolation amongst diasporic communities because it enabled them to cling on to familiar cultural forms from the Indian subcontinent. As Taz suggested:

'I think a lot of Asians played cricket in Pakistan before they came over. Obviously, over there, the team was eleven Asians ... eleven Pakistanis playing in a team. So maybe, playing cricket together reminds them a little bit of 'back home'. But it also allows us to mingle in.' 39

In recent times the UK has witnessed a steady rise in Asian leagues and teams. Given the increase in numbers of younger South Asians in Britain and their passion for cricket, Johal argues that it was only a matter of time before they would form their own Asian teams. ${ }^{40}$ The growing number of Asian teams meant that leagues consisting exclusively (or almost exclusively) of Asian teams were, therefore, a natural development.

However, within the colonies, Hughson argues, 'cricket was initially kept by the British for themselves, there being no apparent intention of teaching the natives to play'. ${ }^{41}$ In 1889 , for instance, Rudyard Kipling was noted as being 'perplexed' that Punjabi boys had been infected with 'cricket mania'. ${ }^{42}$ Thus, rather than adapting the game's customs to better reflect specific local cultures, parties touring British colonies actively sought to replicate the apparently superior forms already being played in England. However, in spite of the fact that cricket was (and continues to be) widely adopted (if not reinscribed with indigenous values) throughout the Indian subcontinent, at the time, the imposition of foreign cultural norms was often ill-received within the colonies and, according to some of the Asian respondents, resentment of such practices still exists amongst second and third generation settlers in the present day. Aylesworth's Addy, for instance, commented how:

'Some Asian people have hatred towards white people ... British people ... because they were ruled for so many years. The history says it. Where was our freedom? Asians were viewed as second-class people.' ${ }^{\prime 3}$ 
Sutherland's Jim, however, was keen to defend these practices by arguing that England has historically held an imaginary monopoly over cricket's mores and values which others should respect. ${ }^{44}$ For many like Jim, a very specific agenda of cultural homogenisation exists in English cricket whereby, if 'outsiders' want to be accepted, they must conform to a normative code of 'Englishness'. This was apparent in a number of the white respondents' oral testimonies. Sutherland's Simon, for instance, utilised the example of England's South African born batsman Kevin Pietersen in arguing that, while the English cricketing authorities may admit players as eligible to play for England if they adhere to certain criteria - English residency in the case of Pietersen - many people within the game demand greater levels of conformity than the authorities:

'I want Kevin Pietersen to develop an English accent because I want South Africans, Australians and everyone else to look at him and see an Englishman because this is our game. But let's face it, it doesn't matter what the ECB (England and Wales Cricket Board) says, he's not English! It's great to see him score shed loads of runs, but, at the same time, I've always got that recognition that, "well Kev, you're not English are you?"'45

In his analysis of the cultural composition of the England cricket team, Stephen Wagg supposes that 'Birthplace has, arguably, continued to be a matter of negligible importance in the selection of the England cricket team throughout the post-Second World War period'. ${ }^{46}$ He argues that English cricket is surrounded by a cultural paradox in that, 'on the one hand, cricket has been an enduring motif of an unchanging (or homogeneous) 'Englishness' while, on the other, particularly since the 1960s, the English cricketing authorities have availed themselves of an ever more malleable definition of English nationality'. ${ }^{47}$ For example, in the 2009 Ashes and Natwest one day series versus Australia, England fielded no fewer than eight players whose ancestry stretches back beyond England. ${ }^{48}$ While the birthplace of England's players was largely unimportant to all respondents in this research, the concept of embodying a consistent and indeed, acceptable, code of 'Englishness' was shared by the vast majority of the white respondents. Lynn for example, recognised that, in cricket, definitions of 'Englishness' and what is constitutive of English people, is changing, but suggested that these conceptualisations remain bound by traditional definitions:

'In cricket, being English is different from being English in normal terms. Obviously in cricket, you're English if you fit in with certain rules. With someone like Kevin Pietersen, I would think of him as a South African who's come over here and made it his home. He might play for England, but he is South African at heart ... he speaks like a South African ... But with someone like Monty [Panesar] who has been brought up over here, l'd say he was an English guy really because when you listen to him, he's just like any other English lad.'49

Alastair also referred to the case of Monty Panesar and how, in spite of his 'visual otherness', his adorning of a patka, for instance, he has been accepted as a legitimate England cricketer: ${ }^{50}$

'Times have changed, Tom because I think people would have [previously] found it hard to accept an Asian playing for England because of their colour and religion. And while Monty is a Sikh, he was born in Luton; he's an English man. I wouldn't say he was as English as me and you because of where he comes from and how he looks, but he's English.' 51

Central to these depictions is the idea that we are witnessing a growing openness and tolerance of difference in our definitions of 'Englishness'/'Britishness'. In saying this, however, Alastair was 
very clear when he added that he did not consider Monty Panesar to be as English as either himself, or myself. Alastair depicts his 'visual otherness' and Indian ancestry as precursors to him being less English than white English people. ${ }^{22}$ The reason for this, I would argue, is because of English cricket's synonymy with 'whiteness'. Nevertheless, the majority of representations of Panesar provide a positive endorsement of him as an individual. Crucially, his 'Asianness' has rarely been identified as a threat to the racial status quo of English cricket. He is, as described by Lynn above, a likeable character; educated, articulate, modest and most importantly, by his own admission, he is proud to be English and to play for England. ${ }^{53}$ In Back et al's terminology he is a 'contingent insider' in that, he is different, but embodies many of the expected characteristics of the normative code of 'Englishness' ${ }^{54}$ As a result, Panesar has managed to negotiate his insider status through his ability to move fluidly between his 'Englishness' and his 'Asianness'. In other words, Panesar's Otherness has been 'sanitised'. ${ }^{55}$ This is not a strong endorsement of English cricket's inclusivity, however, because it demonstrates that, for ethnic minorities, there are terms and conditions applied to their level of 'Englishness'/'Britishness'. Nevertheless, attempts by established groups to integrate outsider people(s) have become fundamental to the power struggles within globalisation and colonial discourses.

\section{Accepting a traditionally English way?}

As much as cricket played a central role in Britain's colonial expansion, it too featured centrally in cultural resistances emerging from people within and who have since migrated from countries previously under colonial control. Indeed, cricket is now a metaphor for the forces of globalisation and a vehicle for asserting new post-colonial identities. ${ }^{56}$ Cricket represents one of the few instances where people, formerly associated with the British Empire, can emerge victorious from interactions with white English people, and, according to many of the Asian respondents, they take great pride from this. As Aylesworth's Addy commented:

'I think it bothers white people that we [Asians]'re good at sports. Especially when it comes to games like cricket ... because the English invented it, but they're not any good at it. It's important for us that we beat you guys. Remember, our country, like many others, was ruled by the Brits. ${ }^{.57}$

Addy's comments question the view that English cricket and its value system were uncritically accepted by recipient cultures within the colonies. For good reason, people within the colonies did not necessarily welcome the presence of either British people or British games. ${ }^{58}$ During times of the British Empire, cricket played within the colonies was segregated along racial lines. In the late nineteenth and early twentieth centuries, for instance, white Europeans dominated the game in India and were renowned for denying indigenous Indians access to the game. The all white Bombay Gymkhana remains the best example of this (despite the fact that, by the late nineteenth and early twentieth centuries, matches between white Europeans and Indigenous Indians (Parsees, Hindus, Muslims and Indian Christians) had become annual events) due to criticisms about the Triangular, Quadrangular and Pentangular tournaments being divisive and anti-communitarian. ${ }^{59}$

Nevertheless, the natural reaction to unwanted cultural domination is resistance. Rather than uncritically accept the culture and games transported by the British, a central feature of the colonial and subsequently, post-colonial periods is how indigenous people within the colonies reinscribed these cultures and games to better reflect their own values. In other words, cultures, communities and peoples whom Britain has attempted to acculturate have tried sternly to maintain their particularities. Manzoor sums up the type of dissonance many of the Asian respondents were constantly at odds with:

The first generation of immigrants knew they were not British. The second generation wanted to be British but were not fully accepted. The third generation, 
the most successful, has become absorbed into the British culture. They have virtually no connection with the land of their parents, and they have grown up with the same cultural diet as their white friends. In many ways, that is a positive thing but the worry is that once British Asians melt entirely into society they will lose the very thing that makes them distinct ... the language, the respect for family ... and so become nothing more than what my father feared all those years ago ... Brits with brown faces. The biggest challenge facing the next generation of young Asians is how to become committed citizens in a modern Britain without forgetting everything about their past. ${ }^{60}$

Ali offered a very insightful example of this in relation to why many British Asians are reticent about abandoning their Asian heritages altogether:

'There is a fear amongst the Asian communities that we could move towards the indigenous culture in Britain and lose our sense of who we are. This has happened to many of our ancestors and the fear we would suffer a similar fate is a strong underlying feature of why Asians, and in particular, Muslims, want to preserve their own identities and values.' 61

Ali offered a number of interesting perspectives on the role of British culture to British Asians. The most provocative of which challenged the common pre-conception amongst white British people that British culture is morally superior to Asian culture:

'British culture is so focussed around drinking and going to the pub. I find drinking in a pub for the whole afternoon or evening such a bore and waste of time. So I can't identify with this as part of my culture. I think that the importance of family in Asian culture, and the erosion of family amongst the indigenous population is another contrasting feature. We put a great deal of emphasis on traditional values ... good values that you can live your life by. British people don't seem to care about these types of thing. Why would I want to be a part of this?'62

For Ali, and others in this research, it was important for them to remain detached from British culture. A number of the Asian respondents noted how their culture and religion made them distinct from British people and they took great pride in this. Crucially, cricket was also perceived as being integral to their Asian identities. West Indians have, for a long time, used cricket to project a distinctive West Indian identity to the rest of the world. ${ }^{63}$ Cricket in the Caribbean has been an important vehicle for Black emancipation from white colonial rule. Similarly, there is a growing literature on the formation of Asian cricket leagues and teams and their role in providing legitimate spaces for Britain's Asian communities to showcase their abilities outside the official structures of the game, which are often perceived to be white dominated and exclusionary. ${ }^{64}$ Therefore, while the development of English cricket and imposition of English mores and values throughout the other cricket playing nations may have been facilitated by the legacy of British imperialism, this did not lead to an unchallenged homogenisation of the game. Instead, recipient nations and cultures have negotiated the acceptability of what they have internalised and these nations and cultures have reinterpreted the game, and its role in their everyday lives.

A number of the Asian respondents were openly critical of the prospect of a homogeneous British cultural dictatorship existing within the game. Many referred to the establishment of Asian leagues/teams as evidence of resistance to the official (white) playing channels. Rarely, however, do small scale resistances pose significant danger to the establishment, or indeed, act as catalysts for larger social change.65 The danger for cultures of resistance is that they are usually trying to destabilise long standing systems of domination. Sutherland's Simon, for instance, commented on the antagonisms between traditionalists and reformists over the current structure of the game. ${ }^{66}$ For most traditionalists, English cricket is epitomised by Test match 
cricket, many of whom do not like cricket's burgeoning emphasis on shorter forms of the game (such as Twenty20), on the basis that they believe they detract from the game's traditional values, as epitomised by Test cricket, such as discipline. English cricket's traditionalists also lament the intrusion of global influences into the game. The speed with which The Indian Premier League (IPL) has developed and its global popularity, in particular, questions what cricket will look like in the future. ${ }^{67}$ Like many traditionalists, Sutherland's Simon cited his surprise over the success of these shorter forms; arguing how they are nothing more than inauthentic additions to Test cricket. ${ }^{68}$ For traditionalists, these adaptations are indicative of a changing world where we live our lives eschewing subtlety whilst demanding instant gratification. ${ }^{69}$ Former editor of Wisden, Graeme Wright for instance, compared the shortened game to the fast food giant, McDonald's, referring to it as universally accessible, virtually pre-digested, quick and uniform. ${ }^{70}$ Thus, for Test match aficionados, these developments are, to adopt a cliché, 'just not cricket'. Or perhaps more appropriately, they are just not 'English' cricket. These developments do, however, represent the type of cricket celebrated outside England, on much of the Indian subcontinent and, on that basis, the fast-paced, devil-may-care approaches expected in these formats, are the very same approaches British Asians are utilising in the leagues to challenge white English hegemonic control. Aylesworth's Ali conceptualised this idea with reference to Yorkshire cricket:

'At Yorkshire [County Cricket Club] and in the mainstream leagues it's all about technique; face down, stand still and all this. When white people see slogging they're angry. It's not cricket is it, Fletch? But tell me, where's the law that says you can't hit sixes? It might not be 'Yorkshire' cricket, but it's certainly 'our' cricket. ${ }^{71}$

The possessive 'our' is important because, throughout the late twentieth and early twenty first centuries, the English have gradually lost their political control over the game. The most significant development being how the International Cricket Council's (ICC) headquarters have relocated from Lord's to Dubai. ${ }^{72}$ The importance of this relocation, not only concerns the decline of England as a political power, both literally and symbolically, but also the rise of so-called lesser nations, such as India, Pakistan and Sri Lanka in the governance of world cricket affairs. The global success of the IPL is another case in point. Given the IPL's global appeal and the unprecedented level of interest in cricket in India, many now believe India represents the game's political and financial epicentre..$^{73}$ The rapid rise of nations from the Indian subcontinent as cricketing superpowers has arguably contributed to the emergence of a series of more confident ethnic identities amongst the British Asian diaspora. Many of the Asian respondents in this research, for instance, expressed delight that the baton of power had moved from England to the Indian subcontinent. Though it should be noted that, as all the Asian respondents in this research were of Pakistani descent, many were not necessarily of the fact that it is India and not Pakistan that has developed the lion's share of power. Nevertheless, Aylesworth's Inzy commented on this changing power dynamic:

'I think English people seem to think they own cricket and it bothers them that they don't really control it. It's fair to say that Asians own cricket now (he smiles). Look at the IPL, English competitions don't have that level of interest. ${ }^{174}$

Challenges to one's cultural superiority, like that of cricket's governance, can produce powerful ethnic reactions on the part of those people previously in power. Perceived threats to England and 'Englishness' have resulted in the emergence of a defensive 'Little Englander' mentality, which harks back to an age when the English/British did dominate. ${ }^{75}$ The evidence from this research supports the existence of little Englanders in league cricket and suggested that a certain kind of insular English nationalism permeates the game; restricting the participation of, and level of opportunity for, many British Asians. This supports the view that many white English people are still handicapped by visions of a homogeneous Britain and, a fundamental aspect of this is erecting strict symbolic boundaries of identification. ${ }^{76}$ In saying this, while many of the white 
English respondents preferred the game to be homogeneous (that is, reflecting a typically white English way), there are always others determined to heterogenise it to better suit their needs.

\section{Post-colonial reinventions}

While sport was undoubtedly used within the colonies as a means of fortifying a collective cultural bond to Empire, the historical development of sports, such as cricket, clearly shows how people of colonised 'races' and ethnic groups have been actively involved in establishing their own sporting cultures. ${ }^{77}$ The idea that sport would promote racial harmony was clearly absurd. While cricket arrived as the game of the colonisers, unlike other forms of culture, it could not remain the exclusive preserve of white colonists. Indeed, the development of cricket in the twentieth and early twenty first centuries is perhaps, best described as a process of de-colonisation and as a 'national re-assertion on the part of the cricket playing nations of the former British Empire'. ${ }^{78}$ In the post-colonial world cricket acts as a site for anxious ethnic and national negotiations. C.L.R. James for instance, has previously identified the significance of cricket for establishing a coherent West Indian identity. ${ }^{79}$ James also highlights that cricket can be used to emphasise racial pride. This is supported by Burton who argues that, while the game itself may still be rooted in notions of 'Englishness', it has been 'injected with a new and specifically West Indian content and meaning.' ${ }^{\prime} 0$ British Asian communities are similarly utilising cricket to empower themselves against their host community's exclusionary practices. Valiotis for instance, argues that Pakistanis have long resented England's monopolistic control of world cricket affairs and, as a result, use cricket to identify themselves as Pakistanis, distinct from British culture. ${ }^{81}$ Take what Aylesworth's Addy said as a case in point:

'A lot of Asian people resent England and its people for how we are treated. Now, there are two ways I could respond to this. The first is to be a loser; join a gang, and do damage to this country and its people. But what's the point? The other way is to play cricket. I play cricket because it gives me pride ... in who I am, where I come from and what my ancestors went through to get me here. ${ }^{82}$

Addy's comments reflect the belief that cricketing nations across the globe have shown how previously oppressed communities may reinvent sport's symbols and meanings to reflect their cultural identity and political aspirations. ${ }^{83}$ British Asian people have arguably displaced the game from its English habitus by producing new playing styles, supporter cultures and popular meanings. Such views have, according to Chris Searle, resulted in the fragmentation of the game along racial and ethnic lines. ${ }^{84} \mathrm{He}$ argues that 'two crickets' are currently being played in England: one is white, traditional and mainstream, the other is Asian or Black, urban and countercultural. ${ }^{85}$ Thus, it could be argued that cricket's elitist gentleman/amateur dichotomy has now taken on a new identity: that of white people versus ethnic minorities. The establishment of the Asian Quaid-I-Azam League in northern England and the distinctly aggressive and anti-etiquette cricket culture that exists is indicative of this. ${ }^{86}$ It is important that minority cultures do this because they can take pride in their non-conformity. However, at the present time, the impact of this non-conformity on the overall structure and governance of the English game has been negligible. Cricket and other reproductive apparatuses of 'Englishness' have been able to banish the resurgence of all kinds of heresies, which threaten traditions of the game. The worldwide condemnation of Kerry Packer's proposed monopolisation of the game through the advent of World Series Cricket and more recently, the reluctance among England's cricket administrators to embrace the IPL by allowing its players to participate in the franchise reflect this. ${ }^{87}$

In ethnic and national terms, however, normative constructions of 'Englishness' depict British Asians, and the Indian subcontinent generally, as the Other, while also trying to stand in the way of their creativity by presenting their approaches to the game as inferior and irrational. In the racialised culture of the British Empire, white settlers ruled indigenous 'coloured' populations, and part of the pretext for this political arrangement was the supposedly greater rationality of white players. This mentality is exemplified in the writings of the Kentonian Lord Harris, who, in the 
introduction to Framji Patel's Stray Thoughts of Indian Cricket, admitted how he 'was never impressed with the Parsee batting' - 'Parsee' being a common phrase used to delineate Indian people. He remarked:

[T]he best of them were liable to throw away their wickets by some rash stroke, due I expect to excitability. To wear down good bowling, and patiently wait for many overs for a run here and a run there, is easier for the phlegmatic Anglo-Saxon than the excitable Asiatic [sic].88

Harris' later remark of how 'the Indian [cricketer] will never be the equal of the Englishman' exemplifies the cultural snobbery that has surrounded the sport for decades. ${ }^{89}$ Certainly, the depiction of minority ethnic communities as representing something different and transgressive, rather than 'normal', is characteristic of the 'deep anxieties within the white community about the threat of 'alien' ways to traditional, or 'white' English culture' during the post-colonial period. ${ }^{90}$ The exoticised racial Other is subjected to the 'historic folk grammar of British racism' where 'animal blacks enjoy an excess of brute physicality and wily oriental gentlemen conversely display a surfeit of cerebral power, while only the authentic Anglo-Brit is able to luxuriate in perfect equilibrium of body and mind'. ${ }^{91}$ This normalising of a white English way and the depicting of a 'deviant' Asian or Black way serves two interdependent purposes. Firstly, it maintains a certain white English stranglehold on the dominant codes of the game and secondly, it aids in rendering the expressive traditions of minority ethnic communities as inauthentic adaptations.

The type of urban and counter-cultural cricket played within Asian communities identified by Chris Searle is often interpreted as being a contradictory form of the game in that, Asian cricketers will readily reject the conservative moral code of English cricket as part of a counter-hegemonic movement motivated around their lack of representation in the game on the whole. ${ }^{92}$ Searle specifically argues that minority ethnic communities (British Asians and British Blacks included) are reinventing this traditionally English game in light of their hybridity:

Now the streets of England ... echo with the sounds of bat, ball and multilingual voices. Where the new communities have arrived, so has their cricket. Ironically, they have brought it with them, their own anti-colonial versions from Kashmir, Barbados, Punjab, Guyana or Lahore - versions freely adapted not from models in London or Bradford, but from a game developed in their countries of origin, learned, applied and emulated from imperial occupiers. ${ }^{93}$

It is not that various versions of the game exist side-by-side or in opposition to one another, however. Rather they are inexorably related in that, each version informs us of the others. McDonald and Ugra argue that, due to their experience of racism and exclusion within mainstream leagues, ethnic minorities will consciously create a very different cricket culture within their own environments. ${ }^{94}$ Often, players from minority ethnic communities will adopt values and behaviours that are the very antithesis of the traditional etiquette of the English game. ${ }^{95}$ British Asians, in particular, are believed to emphasise a spirit of competitiveness, which places less importance on playing within the 'spirit of the game' than it does on winning. However, while such acts of resistance are crucial to British Asians' sense of belonging, they often exacerbate already fragile relationships between themselves, white English people and the game.

For example, a number of the Asian and white respondents recalled examples from their youth when talented Asian and Black players had been overlooked by both county teams and top league clubs because their way of playing, and their way of expressing their identity, transgressed the normality of white English cricket. Aylesworth's Ali, in particular, believed that identifying the freedom with which Asians play as evidence of technical and intellectual deficiencies was an unjustified excuse for maintaining the status quo within the game: 
'There are awesome Asian cricketers who play with the 'wrong' technique. They're unorthodox. If you take that away, they're not going to be as good are they? You shouldn't presume that one way of playing cricket is better. I see that as being biased against Asians. It's an attack at Asian things. I respect the white guys and the things they do and I expect the same in return. But it doesn't happen like that unfortunately. White guys don't respect the way we play. ${ }^{9} 6$

Ali's comments are significant because they imply that firstly, in cricket, a number of different approaches to the game exist and they exist along ethnic lines; secondly, that the value of these alternative approaches is judged against a normative white English version; and finally, Asian and Black people are excluded from certain forms of the game because they do not successfully embody, or are reluctant to endorse, the moral code of English cricket expected of them.

In relation to this, it has been argued that, much of England's cricketing demise throughout the 1980 s and early 1990s, lay in its inability to tap into its non-white talent. ${ }^{97}$ In addition, there is evidence suggesting that interest in cricket amongst white English people (principally young people) is declining, whilst interest amongst British Asians continues to grow. ${ }^{98}$ As a result, since the 1990s, there has been a conscious drive by the English cricket authorities to develop a number of inclusion initiatives, specifically targeted at ethnic minorities. The most well cited in the case of Yorkshire County Cricket Club was the establishment of the Black and Ethnic Minority Cricket forum in 1993. The forum was set up in order to (amongst other things) promote opportunities for ethnic minorities, to support the development of ethnic minority clubs, and to eliminate racial disadvantage and discrimination. ${ }^{99}$ However, even after the establishment of the forum, and subsequent strategy documents, the role of ethnic minorities in Yorkshire cricket continues to be contested and success of the forum is difficult to quantify. In spite of this, many of the Asian respondents believed that the relationship between white clubs and Yorkshire's Asian communities was getting better. For certain, league cricket in Yorkshire is becoming more culturally diverse and, more than ever before, we are witnessing an amalgamation of different cricket cultures. Indeed, the belief that cricket plays an important role in integrating minority ethnic communities was shared by the vast majority of the white respondents; most of whom agreed that a person's ethnicity was irrelevant as long as they were good players and likeable people. As Sutherland's Jeff commented:

'I couldn't give a toss whether they [players]'re Black, white or yellow; whether they're English, Pakistani or an Afghan. If a player is good enough and they can make the team better, it just doesn't matter to me.'100

The result of this kind of mentality is that recreational teams are becoming far more ethnically diverse. Whereas once, nearly all teams in Yorkshire were exclusively white, it is becoming normal for each team to have at least two or three British Asian representatives; not to mention, overseas players from the Indian subcontinent. I argue that the proliferation of such indifference to the ethnic make-up of cricket teams reflects the current era of competitiveness and globalisation where, as indicated by Jeff above, the demand for unequivocal 'English', 'Yorkshire', or 'whoever' players is second only to the desire to win. At the present time, the high monetary and commercial benefits, not to mention kudos, received for being a successful team, should be more important than the 'race' and/or ethnicity of the team.

Cricket has changed because it, like everything else, has been influenced by global flows (people, technology, money), commensurate with the burgeoning influence of multimedia conglomerates such as BSkyB. ${ }^{101}$ The scope of cricket's globalisation is, however, debateable. Rumford argues that because elite cricket is restricted to the ten full Test-match-playing nations, all of which have been associated with the British Commonwealth, it does not have strong global appeal and possesses a low profile outside these nations. ${ }^{102}$ Rumford states that cricket 'will never go global'. ${ }^{103}$ However, cricket is already global. Cricket may not draw the same level of global audiences as football, for instance, and its mass appeal remains highly saturated in the 
traditional cricket playing nations, but it remains the case that cricket is played on five continents and, in addition to its ten full playing members, the ICC boasts 94 'associate' and 'affiliate' member countries, which are spread across the globe and represent diverse cultures: from the USA to the newest affiliate member, Afghanistan (in 2008).

While cricket has remained stubbornly English for a long time, the game has, in recent times, been subject to serious re-evaluation, with many of its distinctive characteristics and qualities being redefined by different cultures. In countries where it has become embedded as a key national sport, if not indeed, the national sport, cricket is no longer considered to be an English game. For example, it has been said that 'Indians have indigenised cricket and that it is more Indian than English'.104 Similarly, in the opening to The Tao of Cricket, Nandy asserts how: 'Cricket is an Indian game accidentally discovered by the English. ${ }^{105}$ Nandy's challenge to the view of cricket being the quintessential English game goes some way to dispute the idea that cricket was merely handed down by the British and compliantly absorbed by the local inhabitants of Empire. ${ }^{106}$ This idea was supported by a number of the Asian respondents. Ali, for instance, told me that, for him, cricket would always be more Pakistani than English because of the importance of cricket within Pakistani culture. ${ }^{107}$ Similarly, Aylesworth's Jimmy argued that football was the national sport in England and thus, as Pakistanis offer unrivalled enthusiasm for cricket, they should have the right to claim it as theirs:

'You guys [English] don't even like cricket. You're all into your football. In Pakistan, the only thing that matters is cricket. Twenty four hours a day, cricket. You can have your football, but cricket is ours.' ${ }^{108}$

Underlying Ali's and Jimmy's comments is the key question of what it means to be an Asian living in Britain. The impact of globalisation on diverse sporting cultures revolves around ideas of negotiation and resistance. Minority ethnic groups constantly have to negotiate their right to belong in sports. Indeed, in the case of cricket, and for British Asians, their ability to resist the hegemonic structures of white 'Englishness', by asserting their own distinctive ethnic identities, is paramount to this negotiation.

\section{Conclusion}

This article has offered an appreciation and understanding of how British Asian cricket identities are multi-layered and heterogeneous. Contrary to what some people might think, the future of cricket does not reside with the English. Cricket is played, consumed and endorsed globally. In fact, cricket is more popular beyond English borders than within them and arguably, is declining in national significance.109 Indeed, cricket is an exception to the globalisation (as imperialism) rule in that, in cricket, it is the non-West (Indian subcontinent) that is developing the lion's share of power. However, even in spite of this shift in power, evidence from this research identifies that England maintains an imaginary hold over the game. Cricket has developed with strict local mythologies, bounded by historical discourse that, even in spite of its globalisation, has allowed it to remain firmly embedded within its indigenous (English) vernacular. ${ }^{110}$ To this day, cricket's global social practices seem to be entrenched within Anglo tradition; albeit, a more sanitised, pluralistic and open version of tradition. ${ }^{111}$ Naturally, with the increasing endorsement of shorter forms of the game, this openness is set to predominate even further. Nevertheless, cricket retains its uniqueness, its mythologies, its difference-making rituals and performances. In this sense, then, homogenisation, while an effect of globalisation, is not necessarily a consequence of it. Despite globalising influences, there still exists an imagined community based around cricket. That is, it is the game of cricket, its attendant history, and it's lived culture, which has created this imagined community which is embodied through our everyday lives. ${ }^{112}$

For many minority ethnic communities, changing the symbolic boundaries of this very English game is fundamental to challenging the game's strictures. However, the influence of minority ethnic communities in Britain has been largely superficial because, despite having adapted the 
traditional value system of the game (by imbuing within it their own distinct value system), they have done little to legitimately challenge the game's organisation and governance. In most instances, these adaptations are individualised responses which function only at the symbolic level. Rarely will adaptations be made on a mass scale with the aim of bringing about significant re-structuring. As a result, it is difficult to quantify the consequences of these adaptations on the game as a whole. While at the symbolic level, barriers have been crossed and boundaries redefined, in the 'real' world very little has, in fact, changed in regards to stripping away the mythologies and invented traditions that still, to some degree, legitimise the control of white English people over the mores and values of the game. For instance, McDonald and Ugra illustrate that white cricket clubs have the power to effect the (continued) exclusion of many ethnic minority cricketers. ${ }^{113}$ Similarly, Searle argues that, despite its quality and significant participation levels, Black and Asian cricket is attributed little status within the hierarchy of English cricket; often having to operate outside official structures of the game, with poor facilities and sparse funding. ${ }^{114}$ Moreover, it continues to be the case that Asian people are under-represented at other levels of the game; as coaches, directors and umpires, for instance, and it is here where the overall power lies. ${ }^{115}$

For many traditionalists cricket continues to be the game of the English, but globalisation is threatening its authenticity. The theme of England as originator of the game casts the British Asian as the copier, the inauthentic player who cannot fully understand cricket because they have not born into it. Moreover, though the ethnic make up of the England team has - and continues to be - anything but exclusively English, the mores and values in English cricket carry on promoting 'Englishness' as something inherent, something which belongs to white English people and, as something that is inaccessible by foreigners. It has been through this notion of originality that English/British people have maintained a cultural monopoly over the game's dominant mores and values. I have argued that the attempted exclusion or assimilation of minority ethnic communities may be best understood as defensive reactions amongst white British people to the perceived threat of minority ethnic communities and their Otherness within the post-colonial epoch. This helps us to understand why, for many, even in the age of globalisation and diversity, nostalgic visions of cricket and 'Englishness' continue to be relevant. As a result, any alternative forms of the game, or any alternative value systems, are constructed as being subordinate because they lack authenticity. In spite of this, the significance attached to these 'alternatives' should not be judged by responses to them, but in how meaningful they are to those individuals involved.

${ }^{1}$ Hughson, The middle class, colonialism and the making of sport.

${ }^{2}$ Burdsey, 'From Ranji to Ravi: The Emergence of the British Asian Cricket Star'.

3 Ibid.

${ }^{4}$ The Marylebone Cricket Club is better known, throughout the cricketing world, as the MCC. Founded in 1787, the MCC is the world's most famous cricket club. The MCC was formerly the governing body of cricket in England and across the world. Most of its global functions were passed on to the International Cricket Council (ICC) in 1993 and its English governance was passed to the England and Wales Cricket Board at the same time.

${ }^{5}$ Marqusee, In search of the unequivocal Englishman: The conundrum of race and nation in

English cricket, 126.

${ }^{6}$ Long et al., Crossing the Boundary. McDonald and Ugra, Anyone for cricket? Equal opportunities and changing cricket cultures in Essex and East London. Carrington and McDonald, Whose Game is it Anyway?. Searle, Pitch of Life.

${ }^{7}$ Long et al., Crossing the Boundary. McDonald and Ugra, Anyone for cricket? Equal opportunities and changing cricket cultures in Essex and East London. Malcolm, Malign or Benign? English National Identities and Cricket.

${ }^{8}$ Space does not allow discussion here of the methodological discourse surrounding the politics of inter-racial research; but for further reference please see Young Jr. (2004) and Fletcher (2010).

${ }^{9}$ Light, In a Yorkshire Like Way.

${ }^{10}$ Searle, Pitch of Life. 
11 Williams, Cricket and Race. Ismail Dawood became YCCC's first British born player of South Asian descent in 2003. Ajmal Shazhad became YCCC's first Yorkshire born player of South Asian descent a year later. A further two British Asians have represented the county: Adil Rashid and Azeem Rafiq (born in Pakistan). YCCC continues to have never fielded a British born Black player.

${ }_{12}$ Ameli, Globalisation, Americanisation and British Muslim Identity.

13 ibid.

${ }^{14}$ Ballard, Desh Pardesh, 9.

${ }^{15}$ Gilroy, After Empire, 126.

${ }^{16}$ Smith, Towards a Global Culture?

${ }^{17}$ Bauman, Globalization. Beck, The Cosmopolitan Society and its Enemies.

${ }^{18}$ Smith, Towards a Global Culture?

19 Interview, $26^{\text {th }}$ February, 2009.

${ }^{20}$ Sandiford, Cricket and the Victorian Society.

${ }^{21}$ Parekh, Rethinking multiculturalism: cultural diversity and political theory.

22 After controversially appearing on the BBC's 'Question Time' programme in October, 2009 Griffin was quoted as saying: '[England] was not my country anymore ... the place is dominated by ethnic minorities. There is an ethnic minority ... the English' (The Guardian October 23rd, 2009). Sadly Griffinesque testimony is evident throughout British history: commenting in the late 1960s Enoch Powell commented: 'every nation is unique ... it has its own pastimes ... memories ... language or ways of speaking, its own ... culture' (cited in Kalra et al., 2005: 31).

23 Tebbit has never retracted his comments. Instead, in August 2005, after the 7 July 2005 London bombings, which were carried out by three young men of Pakistani descent and one of Jamaican descent, Tebbit claimed vindication for these views.

${ }^{24}$ A great deal of media and political rhetoric exists on viewing 'Englishness'/'Britishness' as some kind of homogeneous state of being. In 1978 for example, Margaret Thatcher, then leader of the Conservative opposition, argued that there was something 'natural' about the British way of life. This was presented in stark contrast to being 'swamped' by immigrant peoples who were set to destabilise the existing commonality between British people (see Nayak, 2003: 156).

${ }^{25}$ Marqusee, Anyone But England, 26.

${ }^{26}$ Sandiford, England.

${ }^{27}$ Mangan, Britain's Chief Spiritual Export: Imperial Sport as Moral Metaphor, Political Symbol and Cultural Bond, 2.

${ }^{28}$ Williams, Cricket and England: A Cultural and Social History of the Inter-war Years.

${ }^{29}$ Sandiford, England. Gemmell, All White Mate?

${ }^{30}$ C.L.R. James, Beyond a Boundary, 163.

31 ibid: 162.

32 Wright, Betrayal: Struggle for Cricket's Soul.

${ }^{33}$ Williams, Cricket and England: A Cultural and Social History of the Inter-war Years.

${ }^{34}$ Hughson, The middle class, colonialism and the making of sport.

${ }^{35}$ Hughson, The middle class, colonialism and the making of sport, 72.

${ }^{36}$ Guha, A Corner of a Foreign Field: The Indian History of a British Sport, 50.

37 Sandiford, England, 1.

${ }^{38}$ Guha, A Corner of a Foreign Field: The Indian History of a British Sport, 5.

39 Interview, 12 December, 2008.

40 Johal, Playing their own game.

${ }^{41}$ Hughson, The middle class, colonialism and the making of sport, 72.

${ }^{42}$ Guha, A Corner of a Foreign Field: The Indian History of a British Sport, 47.

43 Interview $2^{\text {nd }}$ March, 2009.

44 Interview, $20^{\text {th }}$ March, 2009.

45 Interview $20^{\text {th }}$ March, 2009.

${ }^{46}$ Wagg, To be an Englishman, 4.

47 ibid: 1.

48 Andrew Strauss, Kevin Pietersen and Jonathan Trott (South Africa); Adil Rashid and Owais Shah (Pakistan); Monty Panesar and Ravi Bopara (India); and Eoin Morgan (Ireland). 


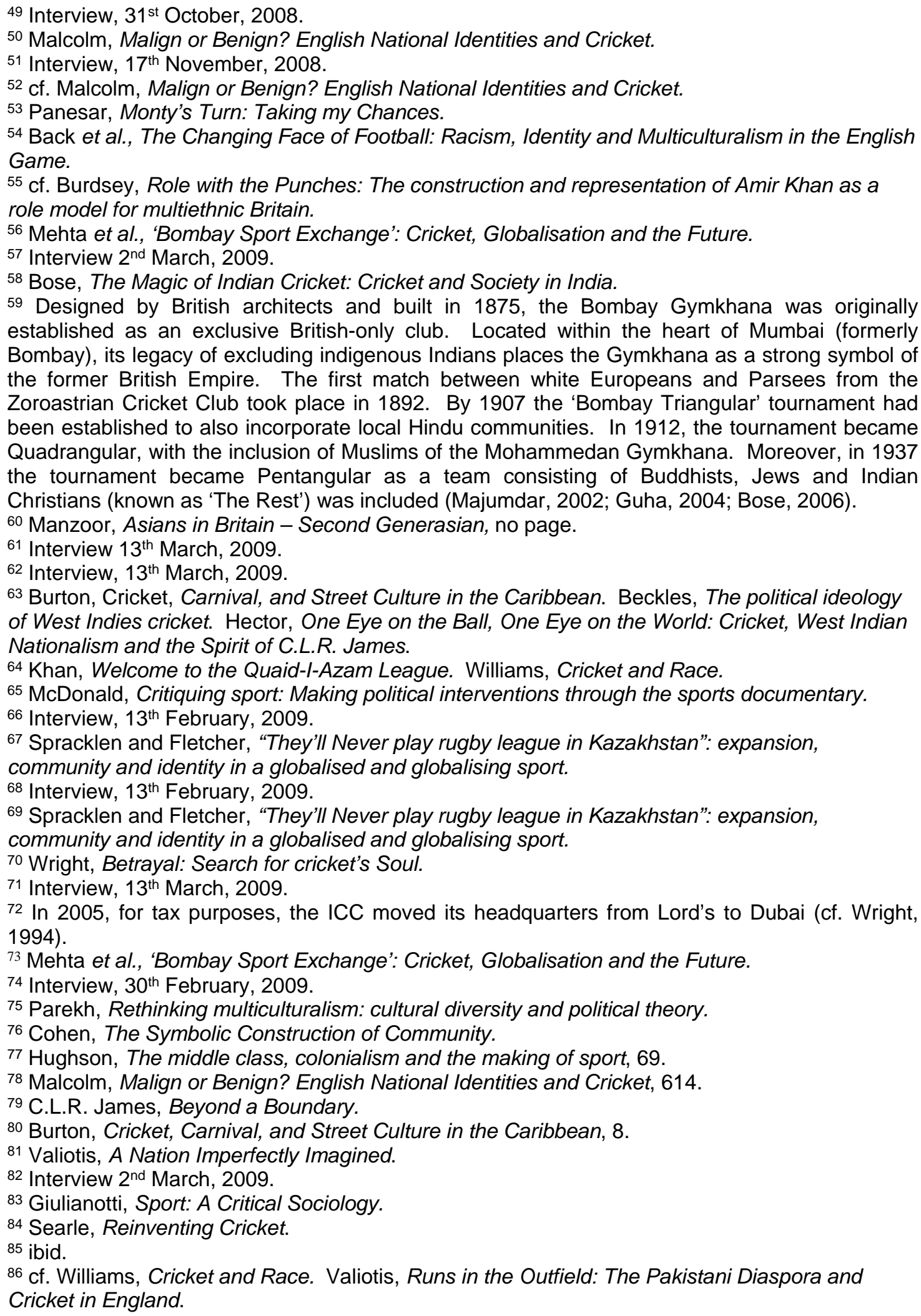


87 cf. Wright, Betrayal: Search for Cricket's Soul. Mehta et al., 'Bombay Sport Exchange': Cricket, Globalisation and the Future.

88 cited in Guha, A Corner of a Foreign Field: The Indian History of a British Sport, 73.

89 ibid: 74.

${ }^{90}$ Crabbe and Wagg, A Carnival of Cricket, 218.

91 ibid. Cultural stereotypes continue to exist in cricket to the extent that cricket correspondents and commentators seem unable to accept that nations are not monoliths - neither are nations and 'races' the same thing (Marqusee, 1996: 22). Oslear and Bannister's book Tampering with Cricket (1996), for example, presents a series of common caricatures of 'race' and nation: one of which is Pakistan. Accordingly Pakistani cricketers are 'volatile by nature', they have a 'naturally volatile character', which has emerged because Pakistan itself is a nation 'bedevilled by instability'.

92 Searle, Reinventing Cricket.

${ }^{93}$ Searle, Reinventing Cricket, pp. 9-10.

${ }_{94}$ McDonald and Ugra, Anyone for Cricket?

95 ibid.

96 Interview $13^{\text {th }}$ March, 2009.

97 Williams, Cricket and Race.

${ }^{98}$ Research conducted into the Chance to Shine scheme at Loughborough University (on behalf of The Cricket Foundation) cites how cricket can have a positive influence on young children's social development and indeed, on the breaking down of cultural boundaries. However, the project also illustrated the precarious position of cricket within the social world of Britain's young people because its presence is under-represented in schools and thus, they rarely get a chance to experience it (Paton in The Guardian, 09/09/2009).

${ }_{99}$ Yorkshire Cricket Board, Yorkshire Cricket Development Strategy 2008-2011.

100 Interview, $8^{\text {th }}$ February, 2009.

101 Mehta, Batting for the flag: cricket, television and globalization in India.

102 Rumford, More than a game: globalization and the post-Westernization of world cricket.

103 ibid: 207.

104 Sethi, 2004 cited in ibid.

105 Nandy, The Tao of Cricket, 1.

106 Hughson, The middle class, colonialism and the making of sport.

107 Interview $13^{\text {th }}$ March, 2009.

108 Interview, 9 ${ }^{\text {th }}$ March, 2009.

109 Gupta, The globalization of cricket: the rise of the non-West.

110 Spracklen and Fletcher, "They'll never play rugby league in Kazakhstan": expansion,

community and identity in a globalised and globalising sport.

$111 \mathrm{cf}$. Malcolm, Malign or Benign? English National Identities and Cricket.

112 Spracklen and Fletcher, "They'll never play rugby league in Kazakhstan": expansion, community and identity in a globalised and globalising sport.

113 McDonald and Ugra, Anyone for Cricket?

114 Searle, Sheffield Caribbean: The story of a Yorkshire cricket club.

${ }^{115}$ Burdsey, 'From Ranji to Ravi: The Emergence of the British Asian Cricket Star'.

\section{References}

Ameli, S. R. Globalisation, Americanisation and British Muslim Identity, London: ICAS, 2004.

Back, L., Crabbe, T., and Solomos, J. The Changing Face of Football: Racism, Identity and Multiculturalism in the English Game, Oxford: Berg, 2001. 
Ballard, R. (editor) Desh Pardesh: The South Asian Presence in Britain, London: Hurst, 1994.

Bauman, Z. Globalization: The Human Consequences, New York: Colombia University Press, 1998.

Beck, U, The Cosmopolitan Society and its Enemies, Theory, Culture and Society 19 no. 1-2 (2002): pp. 17-44.

Beckles, $\mathrm{H}$. The political ideology of West Indies cricket. In Liberation Cricket: West Indies Cricket Culture, edited by B. Stoddart., and H. Beckles (foreword by Vivian Richards), Manchester: Manchester University Press, 1995.

Bose, M. The Magic of Indian Cricket: Cricket and Society in India, London: Routledge, 2006.

Burdsey, D. 'Role with the punches: The construction and representation of Amir Khan as a role model for multiethnic Britain', Sociological Review 55, no. 3 (2007): pp. 611-31.

Burdsey, D. 'From Ranji to Ravi: The Emergence of the British Asian Cricket Star', (paper presented at the University of Huddersfield Cricket Research Centre Guest Lecture Series, University of Huddersfield: Huddersfield. May 19 $\left.9^{\text {th }}, 2010\right)$.

Burton, R. Cricket, Carnival, and Street Culture in the Caribbean. In Sport, Racism, and Ethnicity, edited by G. Jarvie, pp. 7-29, London: Falmer Press, 1991.

Carrington, B. and McDonald, I. Whose game is it anyway? Racism in local league cricket. In 'Race', Sport and British Society, edited by B. Carrington and I. McDonald, pp. 49-69, London: Routledge, 2001.

Cohen, A. P. The Symbolic Construction of Community, London: Tavistock, 1985.

Crabbe, T., and Wagg, S. (2005) 'A Carnival of Cricket?' The Cricket World Cup, 'race' and the politics of carnival. In Cricket and National Identity in the Postcolonial Age, edited by S. Wagg, pp. 204-223, London: Routledge.

Fletcher, T. "Being Inside and Outside the Field". An Exploration of Identity, Positionality and Reflexivity in Inter-racial Research. In Leisure Identities and Authenticity, edited by D. Chatziefstathiou and L. Mansfield, pp. 77-96, LSA Publication No. 107. Eastbourne: Leisure Studies Association, 2010.

Gemmell, J. All White Mate? Cricket and Race in Oz, Sport in Society 10, no. 1 (2007): pp. 33-48.

Gilroy, P. After Empire, London: Routledge, 2004.

Giulianotti, R. Sport: a critical sociology, Cambridge: Polity Press, 2005.

The Guardian. Griffin: Unfair that Question Time was filmed in 'ethnically cleansed' London [Online] available from http://www.guardian.co.uk/politics/2009/oct/23/bnp-nick-griffin-questiontime, 2009.

Guha, R. A Corner of a Foreign Field: The Indian History of a British Sport, London: Picador, 2002.

Gupta, A. The globalization of cricket: the rise of the non-West, International Journal of the History of Sport 21 (2004): pp. 257-276. 
Hector, T. (2005) One Eye on the Ball, One Eye on the World: Cricket, West Indian Nationalism and the Spirit of C.L.R. James. In Cricket and National Identity in the Postcolonial Age, edited by S.Wagg, pp 159-177, London: Routledge

Hughson, J. The middle class, colonialism and the making of sport, Sport in Society 12, no. 1 (2009): pp. 69-84.

James, C.L.R. Beyond a Boundary, London: Yellow Jersey Press, 2005[1963].

Johal, S. Playing their own game: A South Asian football experience. In 'Race', Sport and British Society, edited by B. Carrington., and I. McDonald. London: Routledge, 2001.

Kalra, V.S., Kaur, R., and Hutnyk, J. Diaspora and Hybridity, London: Thousand Oak, 2005.

Khan, A. Welcome to the Quaid-I-Azam League, in Hit Racism for Six: Race and Cricket in England Today, London: Wernham, 1996.

Light, R. 'In a Yorkshire Like Way': Cricket and the Construction of Regional Identity in Nineteenth-century Yorkshire, Sport in History 29, no 3 (2009): 500-518.

Long, J., Nesti, M., Carrington, B., and Gilson, N. Crossing the Boundary: A study of the nature and extent of racism in local league cricket, Leeds: Leeds University Working Papers, 1997.

Majumdar, B. Cricket in Colonial India: The Bombay Pentangular, 1892-1946, International Journal of the History of Sport 19, no 2 (2002): 157-188.

Malcolm, D. Malign or Benign? English National Identities and Cricket, Sport in Society 12, no. 45 (2009): pp. 613- 628.

Mangan, J.A. (1992) 'Britain's Chief Spiritual Export: Imperial Sport as Moral Metaphor, Political Symbol and Cultural Bond'. In The Cultural Bond: Sport, Empire, Society, edited by J.A. Mangan, pp. 1-10, London: Frank Cass.

Manzoor, S. Asians in Britain - Second Generasian [Online] available from http://www.gho.englisch.de/Courses/2005-2006/En-12/postcolonial/Manzoor.pdf, 2004.

Marqusee, M. Anyone but England: Cricket and the National Malaise, London: Verso, 1994.

Marqusee, M. Race, nation and reality, in Hit Racism for Six: Race and Cricket in England Today, London: Wernham, 1996.

Marqusee, M. In search of the unequivocal Englishman: The conundrum of race and nation in English cricket. In 'Race', Sport and British Society, edited by B. Carrington., and I. McDonald, pp. 121-132, London: Routledge, 2001.

McDonald, I. Critiquing sport: Making political interventions through the sports documentary, (paper presented at the Political Studies Association's 'Critiquing Sport: Theory and Practice' Conference, Leeds Metropolitan University: Leeds. February $\left.26^{\text {th }}, 2010\right)$.

McDonald, I., and Ugra, S. Anyone for cricket? Equal opportunities and changing cricket cultures in Essex and East London, London: University of East London Press, 1998.

Mehta, N. Batting for the flag: cricket, television and globalization in India, Sport in Society 12, no 4-5 (2009): 579-599. 
Mehta, N., Gemmell, J., and Malcolm, D. 'Bombay Sport Exchange': Cricket, Globalisation and the Future, Sport in Society 12, no. 4-5 (2009): pp. 694-707.

Nandy, A. The Tao of Cricket, Oxford: Oxford University Press, 2000.

Nayak, A. Race, Place and Globalization: Youth Cultures in a Changing World, Oxford: Berg, 2003.

Oslear, D., and Bannister, J. Tampering with Cricket, London: HarperCollins, 1996.

Panesar, M. Monty's Turn: Taking my Chances, London: Hodder, 2007.

Parekh, B. Rethinking multiculturalism: cultural diversity and political theory (2nd edition).

Basingstoke: Palgrave Macmillan, 2006.

Paton, G. Cricket 'helps cut bad behaviour' [online] available from http://www.telegraph.co.uk/education/6157728/Cricket-helps-cut-bad-behaviour.html, 2009.

Rumford, C. More than a game: globalization and the post-Westernization of world cricket, Global Networks 7, no. 2 (2007): pp. 202-214.

Sandiford, K. A. P. Cricket and the Victorian Society, Journal of Social History 17, no 2 (1983): 303-317.

Sandiford, K. A. P. (1998) England. In The Imperial Game: Culture, Cricket and Society, edited by B Stoddart and K. A. P. Sandiford, pp. 9-33, Manchester: Manchester University Press.

Searle, C. Reinventing Cricket, in Hit Racism for Six: Race and Cricket in England Today, London: Wernham, 1996.

Searle, C. Pitch of Life: Writings on Cricket, Manchester: The Parrs Wood Press, 2001.

Searle, C. Sheffield Caribbean: The story of a Yorkshire cricket club. In Cricket and National Identity in the Postcolonial Age, edited by S. Wagg, pp. 223-232, London: Routledge, 2005.

Smith, A.D. Towards a Global Culture? In Global Culture: Nationalism, Globalization and Modernity, edited by M. Featherstone, London: Sage, 1990.

Spracklen, K., and Fletcher, T. '“They'll never play rugby league in Kazakhstan": expansion, community and identity in a globalised and globalising sport'. In Tourism and Leisure: Local Communities and Local Cultures in the UK, edited by J. Caudwell, pp. 121-142. LSA Publication No. 105, Eastbourne: Leisure Studies Association, 2009.

Valiotis, C. A Nation Imperfectly Imagined. In Cricket and National Identity in the Postcolonial Age, edited by S. Wagg, pp. 110-131, London: Routledge, 2005.

Valiotis, C. Runs in the Outfield: The Pakistani Diaspora and Cricket in England, The International Journal of the History of Sport 26, no. 12 (2009): pp. 1791-1822.

Wagg, S. 'To be an Englishman': Nation, Ethnicity and English Cricket in the Global Age, Sport in Society 10, no. 1 (2007): pp. 11-32.

Williams, J. Cricket and England: A Cultural and Social History of the Inter-war Years, London: Frank Cass Publishers, 1999. 
Williams, J. Cricket and Race, Oxford: Berg, 2001.

Wright, G. Betrayal: Struggle for Cricket's Soul, London: H. F. and G. Witherby, 1994.

Yorkshire Cricket Board. Yorkshire Cricket Development Strategy 2008-2011 [online] available from www.ycb-yca.org.uk/YCBDevStrat2008-2011.pdf, 2007.

Young Jr. A. Experiences in ethnographic interviewing about on race. In Researching race and racism, edited by M. Bulmer and J. Solomos, pp. 187-202, London: Routledge, 2004. 